J. Perinat. Med. 8 (1980) 150

\section{Behavioral states and breathing activity in the fetus near term}

\author{
H. D. Junge, H. Walter
}

Dept. of Obstetrics and Gynecology, University of Würzburg, Federal Republic of Germany
Measurement of fetal breathing movements (FBM) has found considerable clinical interest recently, because it is thought to be predictive of fetal health or compromise.

However, from our investigations on fetal state behavior [7, 8] methods for assessing FBM generally used so far seem to be inadequate and results are suspect of being unreliable: in the fetal lamb and in the rhesus monkey fetus FBM were found to be associated only with active sleep $[3,6$, 15 ], and in our investigations in the human fetus we found a duration of quiet sleep periods of $20.4 \pm 7.0 \mathrm{~min}$ (Mean \pm SD) and a duration of active sleep periods of $56.6 \pm 20.3 \mathrm{~min}$ [7]. Thus results of FBM measurements might be influenced substantially by the ratio of quiet and active sleep within short FBM observation periods of $30 \mathrm{~min}$ duration, used by the majority of investigators. This influence on. FBM measurements would be independent of the fetal health state.

For a better insight into this problem we performed and evaluated a series of simultaneous recordings of FHR and fetal motor activity (both for assessment of state behavior) and FBM in uncomplicated pregnancies near term.

\section{Material and method}

Twenty patients were selected for this evaluation. Gestational age was $38-41$ weeks in 18 cases and 36 weeks in 2 cases. Observations were performed in the early afternoon.
A drink containing $50 \mathrm{~g}$ of glucose was given 30 to $45 \mathrm{~min}$ prior to the recording period and smoking was not allowed during that time:

Patients were transfered to a quiet dark room. Electrodes were attached to the mother's abdomen for recording of FECG and FHR on a HEWLETT PACKARD 8021 A cardiograph with $1 \mathrm{~cm} / \mathrm{min}$ strip chart time base. Observations of fetal chest movements and fetal motor activity were performed with an ADR real-time scanner, which was combined with a TD recorder for analog recording of chest movements [11]*. The transducer operated at a frequency of $3.5 \mathrm{MHz}$. It was kept in proper position by a special device developed by the author. Because recording breathing movements with the TD recorder was not successful in all cases and at any time breathing movements were addtionally identified with an event marker operated by an observer watching the ADR display. Fetal body movements were identified with the same technique. FHR, body movement marks, chest movement marks and the analog output from the TD device together with a time code (SYSTRON DONNER Time code generator/reader Model 8150) were recorded on analog tape (AMPEX 2200). Recording was stopped when, according to FHR and motor activity pattern, at least

\footnotetext{
* We are very much indebted to the KRANZBÜHLER \& SOHN Comp., Solingen, FRG for generously supplying us with the ADR and TD recorder equipment.
} 
one complete sleep cycle of the fetus was recorded or if the patient began to feel uncomfortable.

Evaluation of the recordings started with defining start and stop of each sleep period according to FHR and motor activity patterns. The principles have been published elsewhere [7]. The percentage of time spent breathing was measured and calculated electronically (INTERTECHNIQUE Physioscope) by accumulating all breath-to-breath intervals shorter than $6 \mathrm{sec}$ and, for control, vice versa the percentage of time spent nonbreathing was measured and calculated by accumulating all intervals equal to or longer than $6 \mathrm{sec}$. Histograms of breath-to-breath intervals $(<6 \mathrm{sec}$ ) were constructed electronically and from these medians and ranges of breathing rate/min were calculated. All calculations were done for each total recording and for each sleep state within the recording separately.

Histograms of nonbreathing periods were constructed electronically as well.

\section{Results}

\subsection{Recording time and duration of sleep cycles}

Duration of recordings was $107.3 \pm 39.5 \mathrm{~min}$ (range 51 to $172 \mathrm{~min}$ ). Total recording time was $2256 \mathrm{~min}$.

For calculation of durations of quiet and active sleep periods all incomplete periods at the beginning and ends of recordings were excluded.

Duration of quiet-sleep-periods was $19.8 \pm 11.1$ min (range 3-35 min), totally $404 \mathrm{~min}$. Duration of active sleep periods was $58.6 \pm 30.7$ min (range 29 to $101 \mathrm{~min}$ ), totally $1748 \mathrm{~min}$. In $4.6 \%$ of total recording time a FHR pattem of "wakefulness" was seen. These results are in absolute agreement with our data published previously.

\subsection{Percentage of time with breathing movements}

Because identification of breathing activity is difficult during periods of "wakefulness" with abundant body movements, these periods were omitted for calculation of the percentage of time with breathing movements.
In $24.3 \pm 16.5 \%$ of time (range $.75-49.0 \%$ ) FBM were present in our total recordings (Fig. 1).

For calculation of breathing activity in respect to sleep states, all incomplete sleep periods at the beginnings and ends of recordings were excluded. During 15 periods of quiet sleep FBM were seen in $13.8 \%$ of time (range 0 to $57.6 \%$ ). In nearly half of these periods no breathing activity at all was seen. But only in 2 of these periods stop and start of breathing coincided with the beginning and end of the period (Fig. 2), whereas in 3 of these periods only stop or start of breathing coincided with beginning or end of the period (Figs. 3, 4). During 8 periods of active sleep FBM were seen in $29.5 \%$ of time (range 5.4 to $43.7 \%$ ), i.e. in none of these sleep periods no breathing activity at all could be seen.

These findings prove that coordination of state behavior and breathing activity is not absolute.

PERCENTAGE OF FETAL BREATHING MOVEMENTS IN RELATION TO SLEEP STATE

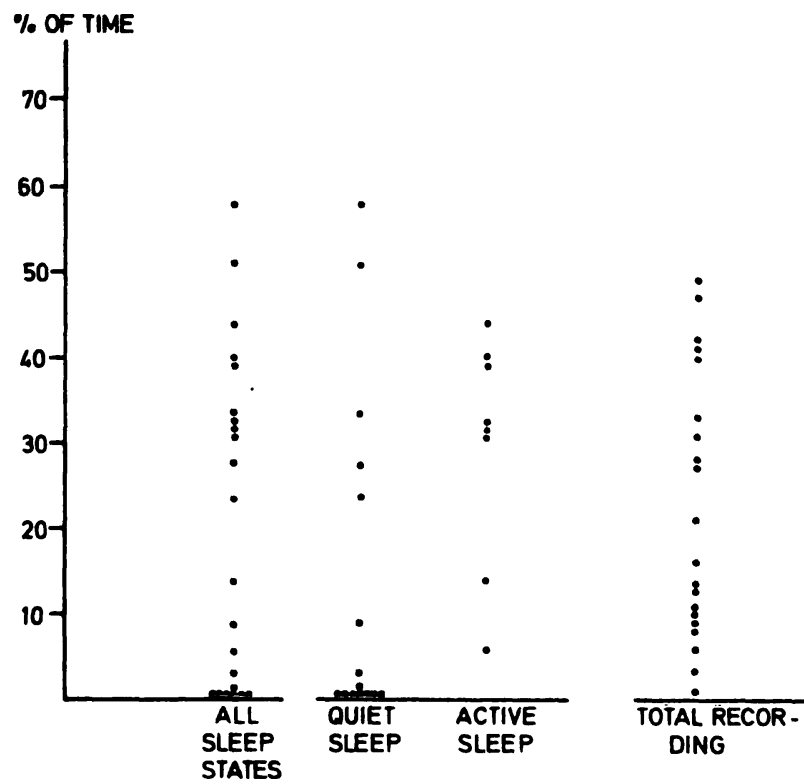

Fig. 1. Percentage of FBM in relation to sleep state. Left: Percentage of FBM calculated in respect to sleep states. A wide range of FBM (0 to 57\%) is demonstrated but in 6 out of 22 no FBM were present. Columns in the center: Percentage of FBM demonstrated for quiet and active sleep separately: Sleep states without FBM are quiet sleep states only. Right: Percentage of FBM calculated in respect to total recording time. In all recordings $F B M$ were present, but in some of them its percentage was very low. 


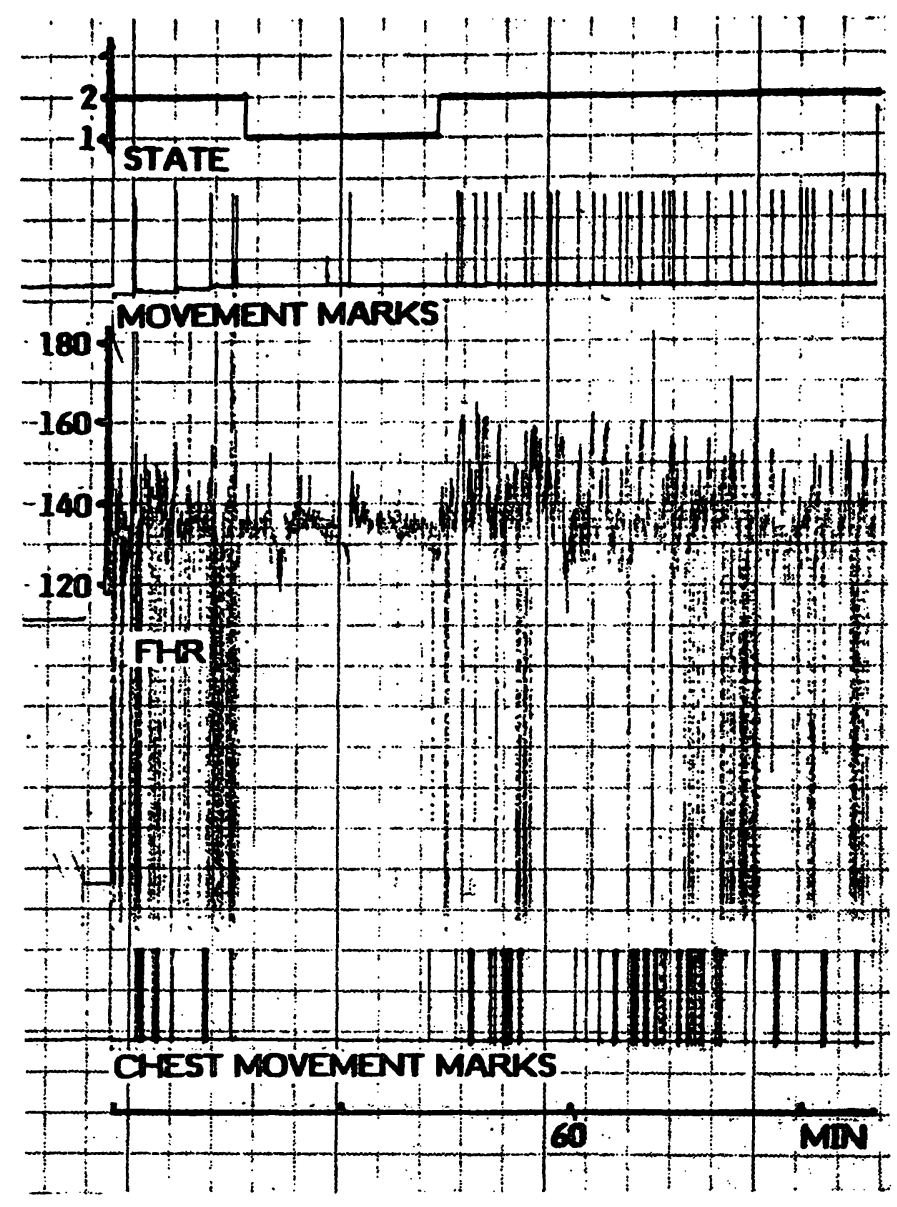

Fig. 2. Simultaneous recording of fetal motor activity and FHR (for definition of sleep state) and FBA. FBM is present during active sleep (State 2) only. No FBM during quiet sleep (State 1).

\subsection{Breathing rate/min}

Medians of breathing rate/min, calculated from the histograms of breath-to-breath-intervals ranged from 38 to 76.5 and the mean value was 61.1 breath/min. Mean values calculated for quiet sleep and active sleep separately were 51.2 and 62.6 respectively $(p=.01)$.

\subsection{Nonbreathing periods}

Corresponding to the practice published in literature $(14,24)$ the absence of breathing for $6 \mathrm{sec}$ or more was taken as nonbreathing.

Duration of nonbreathing periods ranged from $6 \mathrm{sec}$ to $46 \mathrm{~min}$.

From the histograms of nonbreathing periods the cumulative distribution of all durations of nonbreathing periods both in respect to the total

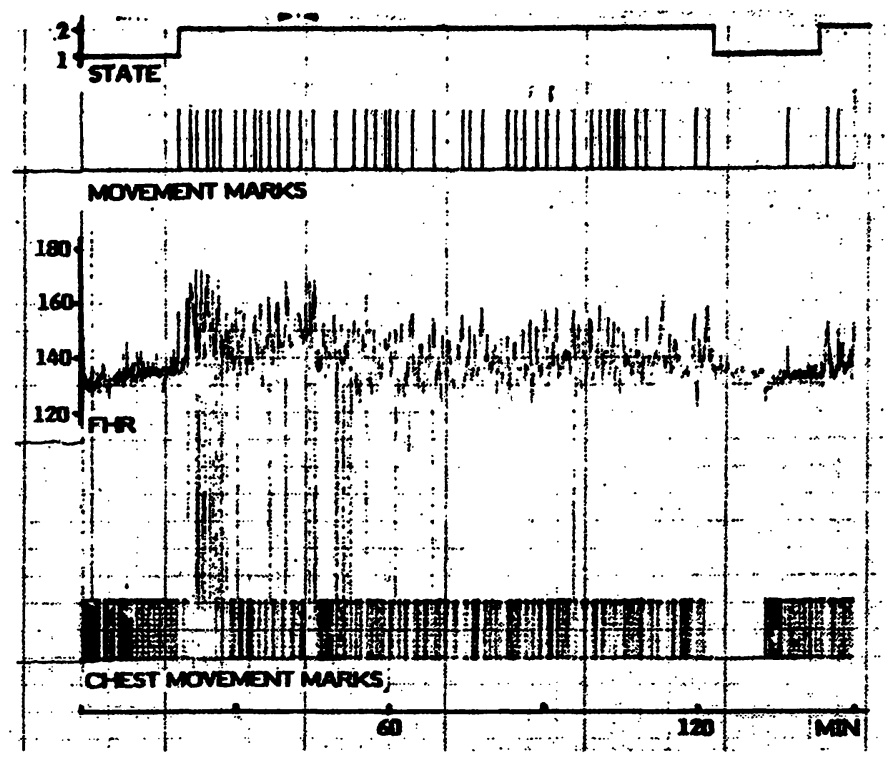

Fig. 3. Simultaneous recording of fetal motor activity and FHR (for definition of sleep state) and FBM. FBM are almost continuous and rapid during the first period of quiet sleep. FBM stop with transition from quiet sleep to active sleep but soon start again and are less regular during active sleep. FBM stop with transition from active sleep to quiet sleep and start again during this period of quiet sleep (see Fig. 8).

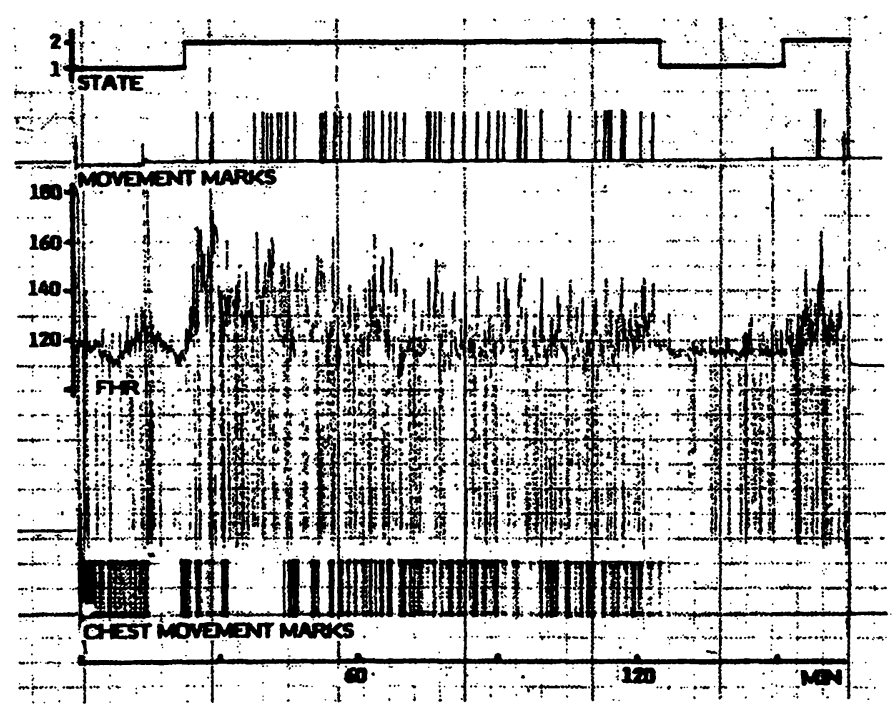

Fig. 4. Simultaneous recording of fetal motor activity and FHR (for definition of sleep state) and FBM. FBM are present during the first period of quiet sleep but stop before change from quiet sleep to active sleep and start again with the beginning of the following period of active sleep. Later FBM stop with the transition from active sleep to quiet sleep but do not start again with the beginning of the following period of active sleep. Later FBM stop with the transition from active sleep to quiet sleep but do not start again with the beginning of the next period of active sleep. 
number $(=100 \%)$ and in respect to total nonbreathing time $(=100 \%)$ were constructed (Fig 5a). These distributions demonstrate that on the one hand nonbreathing periods from 6 to less than $12 \mathrm{sec}$ contributed $58 \%$ of all nonbreathing periods but only $13 \%$ of total nonbreathing time. On the other hand nonbreathing periods of $10 \mathrm{~min}$ and longer contributed only $1.4 \%$ to the number of all nonbreathing periods, but $30 \%$ to total nonbreathing time, periods of $30 \mathrm{~min}$ and longer contributed only .22\% to the number, but still $10 \%$ to total nonbreathing time.

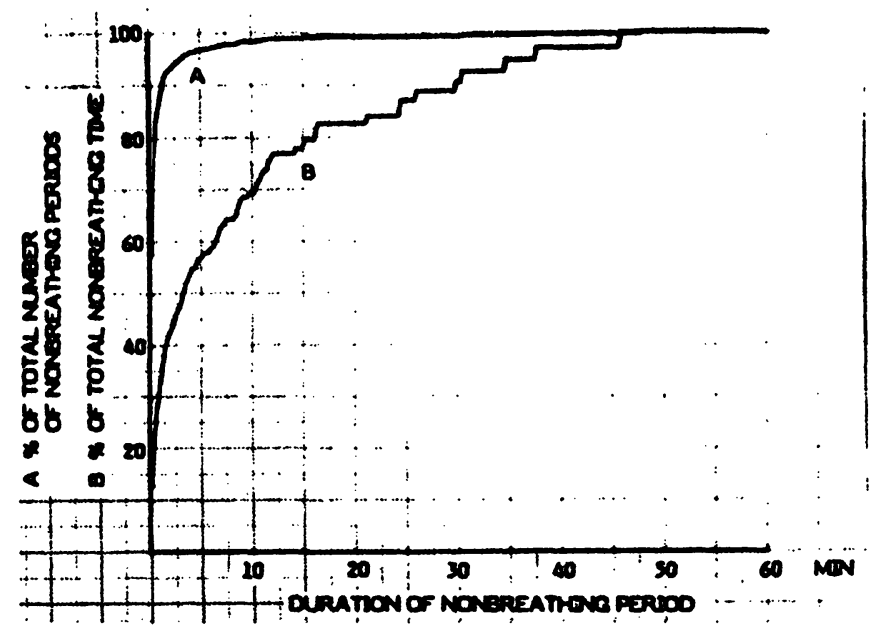

a
An interesting finding is the different shape of cumulative distributions for quiet and active sleep. Distribution for quiet sleep are shifted to longer nonbreathing periods compared to distribution for active sleep (Fig. 5b). This is partly due to data from quiet sleep periods without any breathing activity, but even after removing these data the shift to longer values can be seen.

Therefore besides calculating the percentage of breathing activity cumulative distribution of nonbreathing periods might be an additional means for verifying differences in breathing patterns.

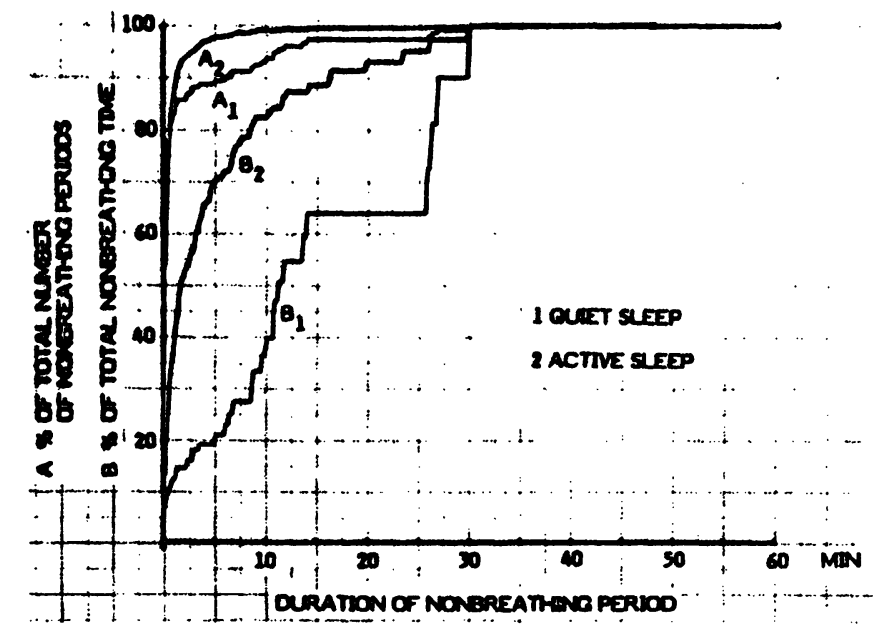

b

Fig. 5a. Cumulative distribution of total number of nonbreathing periods (A) and cumulative distribution of total nonbreathing time $(B)$ in respect to duration of nonbreathing periods.

Fig. 5b. Same as $5 a$ but separately for quiet sleep $\left(A_{1}, B_{1}\right)$ and active sleep $\left(A_{2}, B_{2}\right)$

\section{Discussion}

Results of our study answer 2 questions

1. Is recording of fetal breathing activity for 30 min duration adequate for diagnosis of fetal distress?

2. Is fetal breathing activity state related?

\section{Ad 1:}

In the course of investigation on fetal physiology DAwEs investigated breathing activity in the fetal lamb and reduction and cessation of FBM was found in hypoxemia [1 a, 17]. This was seen in the fatal rhesus monkey too [15]. In conse- quence human fetal breathing activity was investigated with various methods and reduced breathing movements in high risk groups and/or the compromised human fetus was seemingly confirmed $[4,13,20,24]$. Therefore it was suggested that decreased FBM is predictive of fetal distress in late pregnancy and observation of fetal breathing was proposed as an additional clinical method of ante partum monitoring. For assessing FBM mainly a $30 \mathrm{~min}$ observation period was used and the percentage of time with breathing movements was calculated.

However, according to our findings periods of nonbreathing of longer duration, compared to a 30 min observation period, do occur quite often 
in a normal fetus, partly due to the influence of state behavior, partly due to presently unknown factors. Therefore evaluations of FBM from 30 min observation periods are suspect of being influenced substantially by factors (besides glucose intake and smoking of the mother $[5,10,12,16])$ other than fetal distress and may not be representative for fetal health or compromise. PATRICK et al. $[18,19]$ who performed continuous recordings of fetal breathing activity for several hours and saw extended periods of nonbreathing, arrived at the same conclusion. So did Bots et al. [1]. In our and their opinion only prolonged recording of fetal breathing with reliable and standardized techniques should be performed in order to investigate fetal breathing activity.

Even better: recording of fetal breathing for assessiment of FBM should always be done simultaneously with FHR and motor activity recording and fetal state behavior, according to FHR and motor activity patterns should be taken into account, i.e. measurements should be done separately for quiet sleep, active sleep (and states of "wakefulness"). Evaluation of recordings should be expanded too: besides calculation of the percentage of time with breathing activity statistical and sequential properties of breathing and nonbreathing periods should be evaluated.

\section{Ad 2:}

In the newborn infant sleep state related differences in respiration are obvious. In fact, the descriptive definition of sleep state according to Prechtl [19] largely depends on these differences of respiratory pattern.

In the human fetus both the existence of breathing activity as well as the existence of behavioral states [7, 23] have been documented, but until now this was not done simultaneously. Breathing activity in the fetal lamb $[3,6]$ and in the rhesus monkey fetus [15] has been reported to be associated only with active sleep, i.e. it is absent during quiet sleep periods. In the human fetus breathing activity is reported to be irregular with more or less long periods of nonbreathing in between. The question arose whether these periods of nonbreathing, like in the lamb fetus, are synchronous with periods of quiet sleep.
According to our present findings coordination of state behavior and breathing activity in the human fetus in only relative.

Breathing movements may stop with the change from active to quiet sleep, be absent during the whole period of quiet sleep and may start again with the beginning of the next period of active sleep. In that case breathing activity is closely state related. An absolute coordination like this could be seen only in a few sleep periods and it never occurred in a complete record of one fetus with several subsequent sleep cycles. End of breathing activity with a change from active to quiet sleep alone or restarting of breathing activity with a change from quiet to active sleep alone could be seen more often. In the first case restart occurred in the following period of quiet sleep or even later during the next period of active sleep. In the second case activity stopped during the following period of active sleep or even later during the next period of quiet sleep.

Sometimes start and stop of breathing activity occurred within a single sleep period, and in this context it must be mentioned, that definition of start and stop is easy as long as breathing activity is continuous, rapid and regular, but may be difficult when it is irregular and in bursts with shorter periods of nonbreathing inbetween.

Still, according to our findings FBM are unevenly distributed in respect to sleep state, they cluster during active sleep and half of the periods of quiet sleep were without any breathing movements.

Thus in the human fetus only a relative and incomplete coordination of the respiratory center and other centers of the central nervous system constituting state behavior may be assumed.

This is in contrast to the animal fetus, where according to the fact that FBM was found to be associated only with active sleep - an absolute coordination must be assumed.

To our mind present information on fetal breathing and its regulation is incomplete. Further investigations with sophisticated recording and analysing techniques are necessary and FBM measurements for clinical assessment of fetal health or distress from sporadic $30 \mathrm{~min}$ observation periods at present should be considered with care. 


\section{Summary}

Measurement of fetal breathing movements (FBM) has found considerable clinical interest since it is thought to be predictive of fetal health or compromise. However, assessments of FBM within short observation periods of $30 \mathrm{~min}$ duration are suspect of being influenced substantially by factors other than fetal distress and therefore may not be representative for fetal health state.

From results of previous investigations it was assumed that fetal state behavior might have a major influence on FBM assessment.

Simultaneous recordings of FHR and fetal motor activity (for assessing of state behavior) and FBM were performed in 20 patients with uncomplicated pregnancies near term. Duration of recordings was $107.3 \pm 39.5 \mathrm{~min}$.

In $24.3 \pm 16.5 \%$ of time (range $.75-49.0 \%$ ) FBM were present in our total recordings.

During 15 periods of quiet sleep FBM were seen in $13.8 \%$ of time (range $0-57 \%$ ). In nearly half of these periods no breathing activity at all was seen. But onyl in 2 of these periods stop and start of breathing move- ments coindiced with the beginning and end of the period, whereas in 3 of these periods only stop or start of breathing movements coincided with the beginning or end of the period.

During 8 periods of active sleep FBM were seen in $29.5 \%$ of time (range 5.4-43.7\%). In none of these sleep periods no breathing at all could be seen.

Duration of nonbreathing periods ranged from $6 \mathrm{sec}$ to $46 \mathrm{~min}$. Nonbreathing periods of $30 \mathrm{~min}$ and longer contributed only $.22 \%$ to the total number of nonbreathing periods but still $10 \%$ to total nonbreathing time.

Results of our study revealed that sporadic measurement of FBM for 30 min duration may be inadequate for diagnosis of fetal health or compromise, because the proportion of FBM in 30 min observation periods may be influenced substantially by factors other than fetal health state.

Furthermore it revealed that coordination of state behavior and breathing activity in the human fetus in only relative.

Keywords: Fetal breathing, FBM, fetal heart rate, fetus, state behavior.

\section{Zusammenfassung}

Verhaltenszustand und fetale Atmung kurz vor der Geburt

Die Registrierung und Quantifizierung fetaler Atembewegungen hat in letzter Zeit zunehmendes klinisches Interesse gefunden, denn es wird angenommen, daß die Überwachung der fetalen Atmung eine Zustandsdiagnose ermöglicht. Wir vermuten jedoch, daß der Prozentanteil mit fetalen Atembewegungen bei kurzer Registierung von nur 30 min Dauer durch zahlreiche Faktoren beeinflußt wird, so daß dieses Maß für Wohlbefinden oder Gefährdung des Feten nicht absolut repräsentativ ist.

Vorangehende eigene Untersuchungen ließen uns vermuten, daß der zyklische Wechsel des fetalen Verhaltenszustandes einen wesentlichen Einfluß auf den Prozentanteil mit fetalen Atembewegungen bei 30 minütiger Beobachtungszeit hat. Deshalb wurden bei 20 Patientinnen mit normaler Schwangerschaft die fetale Herzfrequenz und die Kindsbewegungen (zur Bestimmung des fetalen Verhaltenszustands) sowie die fetalen Atembewegungen simultan registriert. Die Registrierungen dauerten 107,3 \pm 39,5 $\mathrm{min}$.

Bezogen auf die Gesamtregistrierdauern aller Patientinnen waren zu 24,3 $\pm 16,5 \%$ der Zeit fetale Atembewegungen nachweisbar.

Bezogen auf 15 Perioden mit ruhigem Schlaf des Feten waren im Mittel in 13,8\% der Zeit Atembewegungen vor- handen. Bei etwa der Hälfte dieser Perioden sahen wir keine Atembewegungen. Aber nur bei zwei Perioden sistierte die Atemaktivität unmittelbar mit dem Beginn der Periode ruhigen Schlafs und begann wieder unmittelbar nach dem Ende dieser Periode, bei drei weiteren dieser Perioden fiel entweder nur das Sistieren der Atmung mit dem Ende des aktiven Schlafes oder der Beginn der Atmung mit dem Beginn des aktiven Schlafes zusammen.

Bezogen auf 8 Perioden mit aktivem Schlaf des Feten waren im Mittel in 29,5\% der Zeit Atembewegungen vorhanden. Keine dieser Perioden ergab absolutes Fehlen von Atembewegungen.

Wir fanden Phasen mit fehlender Atemaktivität von $6 \mathrm{sec}$ bis 46 min Dauer. Phasen ohne Atemaktivität von über 30 min Dauer machten nur ,22\% der Gesamtzahl dieser Phasen aus, sie waren aber zu $10 \%$ an der Gesamtbeobachtungszeit mit fehlender Atemaktivität beteiligt.

Nach unseren Ergebnissen scheint also die sporadische Beobachtung der fetalen Atemaktivität für jeweils 30-min Dauer für die Überwachung des Feten nicht uneingeschränkt geeignet.

Weiterhin zeigen unsere Untersuchungen, daß beim menschlichen Feten nur eine relative Koordination zwischen Verhaltenszustand und Atemaktivität besteht.

Schlüsselwörter: Fetale Atembewegungen, fetale Atmung, fetale Herzfrequenz, Fetus, Verhaltenszustand.

\section{Résumé}

Comportement foetal et activité respiratoire chéz le foetus près du terme.

L'enregistrement et la quantification des mouvements respiratoires foetaux éveille un interêt croissant puisque l'on suppose que la surveillance de la respiration foetale permet l'approche de la condition de celui-ci. Il nous semble cependant, que le pourcentage de foetus présentant des mouvements respiratoires à l'enregistrement court 
de 30 minutes seulement et soumis à l'influence de nombreux facteurs, de sorte que ce critère de bien-être ou de souffrance du foetus n'est pas absolument représentatif.

Nos travaux antérieurs nous laissérent supposer, que le changement cyclique du comportement foetal exerce une influence prédominente sur le pourcentage des mouvements respiratoires foetaux au cours d'une surveillance de 30 minutes. Pour cette raison nous avons entrepris au cours de 20 grossesses normales l'enregistrement simultanée de la fréquence cardiaque foetale et des mouvements foetaux (en vue de la détermination de la condition foetale) ainsi que des mouvements respiratoires foetaux. Ces enregistrements ont eu une durée de 107,3 $\pm 39,5$ minutes.

Rapporté au temps total d'enregistrement de l'ensemble des patientes, le temps des mouvements respiratoires foetaux représentait $24,3 \pm 16,5 \%$.

Rapporté aux 15 périodes de sommeil foetal profond, le temps de mouvements respiratoires foetaux représentait en moyenne $13,8 \%$. Environ la moitié de ces périodes ne comportait aucun mouvement respiratoire. Cependant seulement au cours de deux telles périodes les mouvements respiratoires cessaient avec le début de la période de sommeil profond et reprenaient immédiatement après la fin de celle-ci; au cours de trois autres telles périodes l'on notait soit uniquement la cessation des mouvements respiratoires au début de la période de sommeil profond, soit la reprise de ceux-ci à la fin du sommeil profond.

Rapporté aux 8 périodes de sommeil rapide du foetus, le temps des mouvements respiratoires foetaux représentait en moyenne $29,5 \%$. Dans aucune de ces périodes les mouvements respiratoires n'étaient absolument absent.

Nous avons noté des phases sans activité respiratoire d'une durée entre 6 secondes et 46 minutes. Les phases sans activité respiratoire de plus de 30 minutes ne représentaient que $22 \%$ de l'ensemble de ces phases, mais leur part par rapport au temps total d'observation sans activité respiratoire s'élevait à $\mathbf{1 0 \%}$.

D’après nos résultats, il apparaît donc que la surveillance sporadique de l'activité respiratoire foetale pour des périodes de 30 minutes n'est pas nécéssairement appropriée pour l'appréciation du foetus.

Nos investigations montrent en outre, qu'il n'existe qu'une relation relative entre le compartement foetal et l'activité respiratoire chez le foetus humain.

Mots-clés: Etat comportemental, foetus, fréquence foetale cardiaque, mouvements respiratoires foetaux, foetus.

\section{Bibliography}

[1] BOTS, R. S. G. M., G. H. B. BROEDERS, D. J. FARMAN, M. J. HAVERKORN, L. A. M. STOLTE: Fetal breathing movements in the normal and growth-retarded human fetus: a multiscan/M-mode echofetographic study. Europ. J. Obstèt. Gynec. Reprod. Biol. 8/1 (1978) 21

[1a] BODDY, K., G. S. DAWES,: R. FISHER, S. PINTER, I. S. ROBINSON: Foetal respiratory movements, electrocortical and cardiovascular responses to hypoxemia and hypercapnia in sheep. J. Physiol. 243 (1974) 599

[2] CHAPMAN, R. L. K., G. S. DAWES, D. W. RURAK, P. L. WILDS: Intermittent breathing before death in fetal lambs. Amer. J. Obstet. Gynec. 131 (1978) 894

[3] DAWES, G. S., H. E. FOX, B. M. LEDUC, G.D. LIGGINS, R. T. RICHARDS: Respiratory movements and rapid eye movement sleep in the foetal lamb. $J$. Physiol. 220 (1920) 119

[4] DAWES, G. S.: Fetal breathing. Amer. Rev. Respirat. Dis. 115 (6II) (1977) 5

[5] GENNSER, G., K. MARSAL, B. BRANTMARK: Maternal smoking and fetal breathing movements. Amer. J. Obstet. Gynec. 123 (1975) 861

[6] HARDING, R., P. JOHNSON, M.E.MCCLELLAND: Laryngeal function during breathing and swallowing in the foetal and newborn lambs. J. Physiol. 272 (1977) 14

[7] JUNGE, H. D.: Behavioral states and state related heart rate and motor activity patterns in the newborn infant and the fetus ante partum - A comparative study. I. Technique, illustration of recordings, and general results. J. Perinat. Med. 7 (1979) 85
[8] JUNGE, H. D.: Behavioral states and state related heart rate and motor activity patterns in the newborn infant and the fetus ante partum. - A comparative study. II. Computer analysis of state related heart rate baseline and macrofluctuation patterns. J. Perinat. Med. 7 (1979) 134

[9] KRAUSE, W., G. ZWACKA: Eine seltene Oszillationsform. Zbl. Gynäk. 100 (1978) 710

[10] LEWIS, P. J., B. J. TRUDINGER, J. MANGEZ: Effect of maternal glucose ingestion on fetal breathing and body movements in late pregnancy. Brit. J. Obstet. Gy naecol. 85 (1978) 86

[11] LINDSTRÖM, K., K. MARSAL, G. GENNSER, L. BENGTSSON, M. BENTHIN, P. DAHL: Device for measurement of fetal breathing movements I. The TD-Recorder. A new system for recording the distance between two echogenerating structures as a function of time. Ultrasound in Med. \& Biol. 3 (1977) 143

[12] MANNING, F. A., C. FEYERABEND: Cigarette smoking and fetal breathing movements. Brit. J. Obstet. Gy naecol. 83 (1976) 262

[13] MANNING, F. A., L. D. PLATT: Fetal breathing movements and the abnormal contraction stress test. Amer. J. Obstet. Gynec. 133 (1979) 590

[14] MARSAL, K.: Fetal breathing movements. Characteristics and clinical significance. Obstet. and Gynec. 52 (1978) 394

[15] MARTIN, CH. B., Y. MURATA, R. H. PETRIE, J. T. PARER: Respiratory movements in fetal rhesus monkeys. Amer. J. Obstet. Gynec. 119 (1974) 939 
[16] Natale, R., J. PATRICK, B. RICHARDSON: Effects of human maternal venous plasma glucose concentrations on fetal breathing movements. Amer. J. obstet. Gynecol. 132 (1978) 36

[17] PATRICK, J. E., K. J. DALTON, G. S. DAWES: Breathing patterns before death in fetal lambs. Amer. J. Obstet. Gynec. 125 (1976) 73

[18] PATRICK, J., W. FETHERSTON, H. VICK, R. VOEGELIN: Human fetal breathing movements and gross fetal body movements at weeks 34 to 35 of gestation. Amer. J. Obstet. Gynec. 130 (1978) 693

[19] PATRICK, J., R. NATALE, B. RICHARDSON: Patterns of human fetal breathing activity at 34 to 35 weeks' gestational age. Amer. J. Obstet. Gynec. 132 (1978) 507

[20] PlatT, L. D., F. A. MANNING, M. LENAY, L. SIPOS: Human fetal breathing: Relationship to fetal condition. Amer. J. Obstet. Gynec. 132 (1978) 514
[21] PRECHTL, H. F. R.: The behavioural states of the newborn infant (A Review). Brain Research 76 (1974) 185

[22] TIMOR-TRITSCH, I., I. ZADOR, R. H. HERTZ, M. G. ROSEN: Human fetal respiratory arrythmia. Amer. J. Obstet. Gynec. 127 (1977) 662

[23] TIMOR-TRITSCH, I. E., J. D. LEROY, R. H. HERTZ, N. C. DEAGAN, M. G. ROSEN: Studies of antepartum behavioral state in the human fetus at term. Amer. J. Obstet. Gynec. 132 (1978) 524

[24] TRUDINGER, B. J., P. J. LEWIS, J. MANGEZ, E. O'CONNOR: Fetal Breathing Movements in High Risk Pregnancy. Brit. J. Obstet. Gynaecol. 85 (1978) 662

Received August 1, 1979. Revised September 22, 1979. Accepted February 29, 1980.

Prof. Dr. H. D. Junge Univ:-Frauenklinik Josef-Schneider-Str. 4 D-8700 Würzburg 